Cite this: Org. Biomol. Chem., 2014, 12, 5304

Received 4th April 2014, Accepted 23rd May 2014

DOI: $10.1039 / c 4 o b 00717 d$

www.rsc.org/obc

\title{
Exploring mutasynthesis to increase structural diversity in the synthesis of highly oxygenated polyketide lactones $\uparrow$
}

\author{
J. M. Botubol-Ares, ${ }^{a}$ M. J. Durán-Peña, ${ }^{a}$ A. J. Macías-Sánchez, ${ }^{a}$ J. R. Hanson, ${ }^{b}$ \\ I. G. Collado ${ }^{a}$ and R. Hernández-Galán*a
}

\begin{abstract}
The enantioselective synthesis of $(2 R, 3 R, 4 E, 8 E)$-3-hydroxy-2,4,8-trimethyldeca-4,8-dienolide (5) by ring-closing metathesis is described. This compound is an analogue of 3,4-dihydroxy-2,4,6,8-tetramethyldec-8-enolide (4) which is a rare 11-membered lactone produced by the fungus, Botrytis cinerea. Mutasynthetic studies with compound $\mathbf{5}$ using two mutants of $B$. cinerea led to the isolation of four new highly oxygenated 11-membered lactones (11-14) in which compound 5 has been stereoselectively epoxidized and hydroxylated at sites that were not easily accessible by classical synthetic chemistry.
\end{abstract}

\section{Introduction}

Botrytis cinerea is a grey powdery phytopathogenic mould that affects a large number of commercial crops. ${ }^{1}$ Its major phytotoxic metabolites are a family of sesquiterpenes with the botryane carbon skeleton ${ }^{2}$ and two groups of polyketides exemplified, on the one hand, by the botcinic and botcineric acids (1) and their cyclic derivatives, the botcinins $(2),{ }^{3}$ and on the other hand, by botrylactone (3). ${ }^{4}$ A related lactone, 3,4-dihydroxy-2,4,6,8-tetramethyldec-8-enolide (4), has been isolated $^{5}$ from a mutant strain of $B$. cinerea. This lactone possesses the same carbon chain as botrylactone with identical functional groups and stereochemistry in the $\mathrm{C} 1-\mathrm{C} 4$ fragments as both the botcinins and botrylactone. This structural homology and the presence of compound $\mathbf{4}$ in cultures of the strains of $B$. cinerea which also produce large amounts of the botcinins suggest that they have a common biosynthetic origin. Compound $\mathbf{4}$ may be a 'shunt' metabolite in this pathway (Fig. 1).

The sequencing of the $B$. cinerea genome led to the development of genetically modified strains lacking the genes which code for the enzymes that are involved in the biosynthesis of the secondary metabolites produced by this fungus. ${ }^{6}$ Studies of the metabolites produced by these mutants permitted the identification of the genes involved in the production of the

\footnotetext{
${ }^{a}$ Departamento de Química Orgánica, Facultad de Ciencias, Universidad de Cádiz, 11510 Puerto Real, Cádiz, Spain.E-mail: rosario.hernandez@uca.es

${ }^{b}$ Department of Chemistry, University of Sussex, Brighton, Sussex BN1 9QJ, UK. E-mail:j.r.hanson@sussex.ac.uk

$\dagger$ Electronic supplementary information (ESI) available: Copies of the ${ }^{1} \mathrm{H}$ NMR and ${ }^{13} \mathrm{C}$ NMR spectra for all key intermediates and final products, 2D NMR of 11-14 as well as nOe spectra of $(E)-5$ and 11-14. See DOI: $10.1039 / \mathrm{c} 40$ ob00717d
}

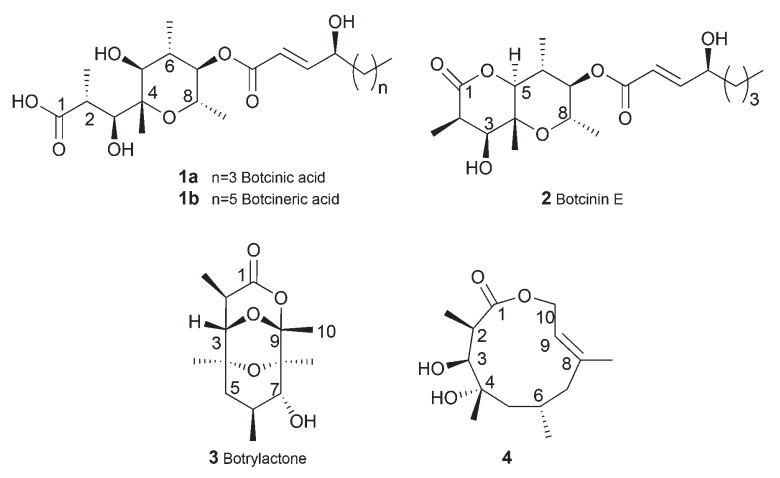

Fig. 1 Some polyketides produced by B. cinerea.

polyketides. ${ }^{7}$ The genes responsible for the formation of the per-methylated tetraketide core of both botcinins (2) and botrylactones (3) are all included in the same cluster comprising genes $B c B O A 1$ to $B C B O A 6$. The latter encodes the polyketide synthase (PKS). ${ }^{6}$

Naturally-occurring medium-sized lactones (8 to 11-membered lactones) are a relatively small number of metabolites which have nevertheless attracted considerable attention because of the range of biological activities which they possess. ${ }^{8}$ In particular there are only a few examples of 11-membered lactones that are found in nature. ${ }^{9}$ Apart from compound 4 and some complex pyrrolizidine and daphniphyllum alkaloids, there are only reports of two insect pheromones, ferrulactone $\mathrm{I}^{10}$ and suspensolide, ${ }^{11}$ and four fungal metabolites including the aspercyclides A-C. ${ }^{12}$ The latter have anti-inflammatory activity and have potential to be used in the treatment of allergic disorders such as asthma. 
The relative thermodynamic instability of 11-membered lactones has made their synthesis and that of their derivatives difficult even using Mitsunobu lactonization ${ }^{13}$ or an intramolecular Reformatsky reaction. ${ }^{14}$ Recently, ring-closing metathesis (RCM) has been developed to provide an efficient method for the preparation of some 11-membered lactones from acyclic precursors. ${ }^{15}$ However RCM reactions in the macrocyclic series tend to give mixtures of the $(E)$ and $(Z)$ isomers of cyclic olefins. A reliable general method for controlling the geometry of the new double bond is yet to be found. ${ }^{16}$ Consequently there are few examples of synthetic analogues whose biological activity has been thoroughly evaluated. Although botrylactone was described by Welmar et $a .^{17}$ as a powerful antibiotic whilst the botcinins have been reported ${ }^{18}$ to show antifungal activity against Magnaporthe grisea, the causal agent of rice blast, nothing is known of the biological activity of compound 4 or its close relatives because of the small amount of material that has been isolated.

Mutasynthesis is a very interesting strategy that combines chemical synthesis with biosynthetically-patterned biotransformations using genetically engineered microorganisms. ${ }^{19}$ The availability of mutants of $B$. cinerea blocked in the early stages of the pathway but retaining some of the later stages leading to these 11-membered lactones has allowed us to explore the use of mutasynthesis to generate modified 11-membered lactones that are analogues of compound 4 in order to evaluate their biological activity.

\section{Results and discussion}

We chose compound 5 as a simplified analogue of compound 4 although the stereochemistry of the alcohol at C-3 is different. However it could be easily synthesized in sufficient quantity for the mutasynthesis experiments. The retrosynthetic analysis of the lactone is shown in Scheme 1. An RCM cyclization of the ester 6 and a syn aldol reaction of the aldehyde 7 play key roles in the stereoselective construction of the 11-membered lactone ring.

The synthetic sequence leading to the lactone $\mathbf{5}$ is shown in Scheme 2. 2-Methyl-2-vinyloxirane was treated with commercially available 2-methylallyl magnesium chloride in the presence of $\mathrm{CuI}$ to produce the allylic alcohol 8 in a yield of $95 \% .^{20}$

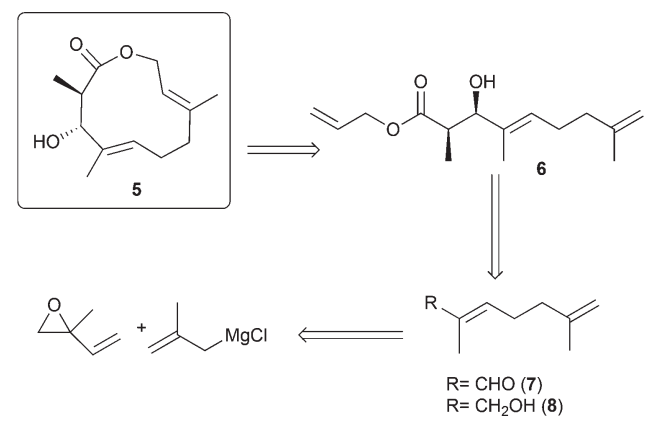

Scheme 1 Retrosynthetic analysis of lactone 5.
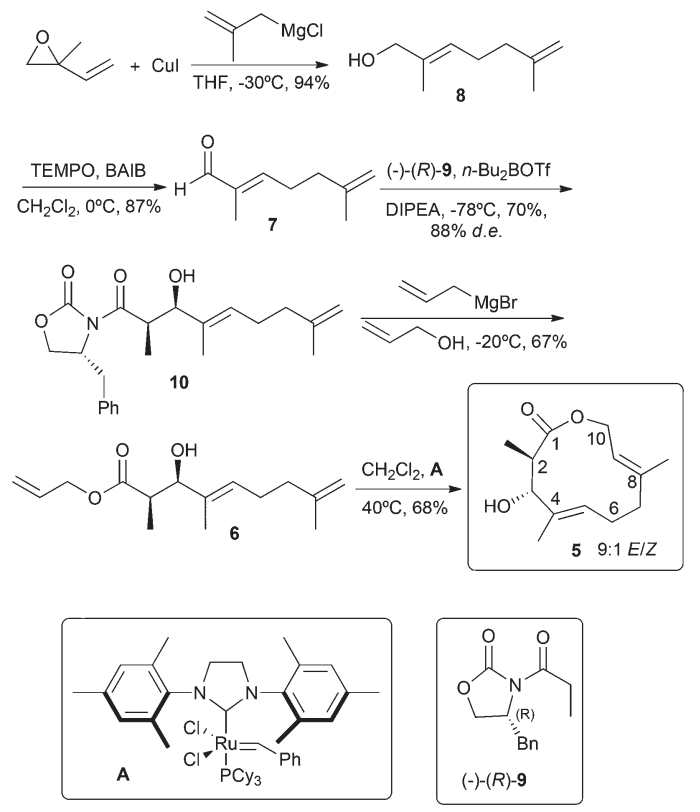

Scheme 2 Stereoselective synthesis of $\mathbf{5}$.

Oxidation of 8 with TEMPO-BAIB (2,2,6,6-tetramethyl piperidinyloxy-bis(acetoxy)iodobenzene) ${ }^{21}$ afforded the aldehyde 7 . This was then treated with the boron $Z$-enolate of the $N$-propionyl oxazolidinone (-)-(R)-9 $\mathbf{9}^{22}$ to give the syn-aldol product 10 in $70 \%$ yield and $88 \%$ de. Exocyclic cleavage of the oxazolidinone 10 with allyl alcohol and 4 eq. of allylmagnesium bromide at $-20{ }^{\circ} \mathrm{C}$ generated the ester 6 with a yield of $67 \%$. Finally an RCM reaction of 6 under high dilution conditions catalysed by the second-generation ruthenium complex $\mathbf{A}^{23}$ in dry, degassed, refluxing dichloromethane produced the 11-membered lactone $\mathbf{5}$ with a good regioselectivity and yield (9:1 E/Z ratio, 68\% yield). $\$ \$$ This is in agreement with molecular mechanics calculations (MM2) which predict that the $(E)$-alkene is the most stable regioisomer. ${ }^{24}$

The lactone 5 was then incubated with two mutant strains of $B$. cinerea, bcbot $2 \Delta$ and bcboa $6 \Delta$ bcbot $2 \Delta$ (bc $\Delta \Delta d 1)$. The first mutant, which was obtained by deactivating the botryane biosynthesis gene $B c B O T 2$ that encodes a sesquiterpene cyclase, ${ }^{25}$ does not produce the botryanes but does produce a significant amount of botcinic acid (1a) and its relatives. The second mutant, $b c \Delta \Delta d 1,{ }^{6}$ is a double mutant which was obtained by deactivating the genes $B c B O T 2$ and $B c B O A 6$ and is consequently unable to produce the three characteristic families of metabolites: the botryanes, the botcinins and the botrylactone. ${ }^{6}$ Incubation of compound $\mathbf{5}$ with both mutant strains using liquid surface-culture conditions gave four new 11-membered lactones 11-14 (Fig. 2). Their distribution and \% yields are shown in Table 1 . The strain bcbot $2 \Delta$ gave a higher conversion of compound 5. The metabolites 11, 12 and 13 were

$\ddagger$ Ratio valuated using ${ }^{1} \mathrm{H}-\mathrm{NMR}$.

$\S$ It is noteworthy that with the first-generation ruthenium catalyst $\mathrm{PhCH}=\mathrm{RuCl}_{2}\left(\mathrm{PCy}_{3}\right)_{2}$, a linear dimer was obtained after $16 \mathrm{~h}$ at reflux in $\mathrm{CH}_{2} \mathrm{Cl}_{2}$. 
<smiles>C/C1=C/C[C@H]2O[C@H]2COC(=O)[C@H](C)[C@@H]1O</smiles>

11<smiles>C/C1=C\C[C@H](O)[C@]2(C)O[C@H]2COC(=O)[C@H]1C</smiles>

13

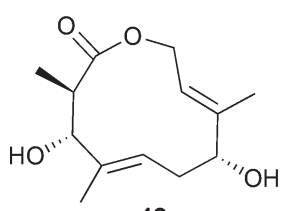

12

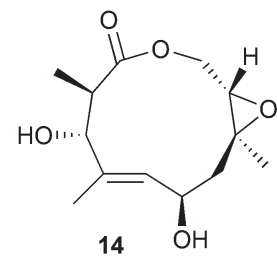

Fig. 2 Metabolites isolated in mutasynthesis.

Table 1 Distribution and yields of isolated metabolites

\begin{tabular}{ll}
\hline Strains & Metabolites (\% yields) \\
\hline bcbot $2 \Delta$ & $\mathbf{5}(3), \mathbf{1 1}(5), \mathbf{1 2}(4), \mathbf{1 3}(19), \mathbf{1 4}(1)$ \\
$b c \Delta \Delta d 1$ & $\mathbf{5}(23), \mathbf{1 1}(15), \mathbf{1 2}(7), \mathbf{1 3}(7)$
\end{tabular}

produced in both cases but there was no apparent incorporation of compound 5 into the botcinin/botrylactone pathway. The structures of the metabolites were established from their ${ }^{1} \mathrm{H}$ and ${ }^{13} \mathrm{C}$ NMR spectra using a combination of $1 \mathrm{D}$ and 2D NMR experiments (see ESI $\dagger$ ).

Compound 11 was obtained as a colourless oil whose HRMS possessed a molecular ion at $\mathrm{m} / \mathrm{z} 240.1353$ corresponding to the molecular formula $\mathrm{C}_{13} \mathrm{H}_{20} \mathrm{O}_{4}$. The ${ }^{13} \mathrm{C}$ NMR spectrum contained resonances at $\delta_{\mathrm{C}} 81.6,62.9,59.8$ and $58.6 \mathrm{ppm}\left(\mathrm{CH}, \mathrm{CH}_{2}, \mathrm{C}\right.$, and $\mathrm{CH}$ carbons respectively) and at $\delta_{\mathrm{C}} 174.4 \mathrm{ppm}$ (C carbon) consistent with the presence of four $\mathrm{C}-\mathrm{O}$ and one lactone $\mathrm{C}=\mathrm{O}$ carbon atoms in the molecule. The main difference between the ${ }^{1} \mathrm{H}$ NMR spectra of compounds 5 and 11 was the absence of the olefinic proton $\mathrm{H}-9$ and the appearance of a double-doublet $(J 10.0$ and $4.2 \mathrm{~Hz})$ at $\delta_{\mathrm{H}} 3.01 \mathrm{ppm}$ in compound 11. The presence of an epoxide at this position was confirmed by an HSQC correlation of H-9 with the signal at $\delta_{\mathrm{C}} 58.6 \mathrm{ppm}(\mathrm{C}-9)$ and $\mathrm{HMBC}$ correlations between $\mathrm{H}-9$ and signals at $\delta_{\mathrm{C}} 59.8(\mathrm{C}-8)$ and $\delta_{\mathrm{C}} 62.9 \mathrm{ppm}$ (C-10). The stereochemistry of the oxirane ring was established by nOe experiments which were rationalized on the basis of the lowest energy optimized conformer derived from MM2 calculations (Fig. 3). ${ }^{24}$ In particular there were interactions between $\mathrm{H}-9$ and $\delta_{\mathrm{H}} 5.17(\mathrm{H}-5), \delta_{\mathrm{H}} 2.16-2.08(\mathrm{H}-6 \beta)$, and $\delta_{\mathrm{H}} 1.08(\mathrm{H}-7 \beta)$ and between the signals at $\delta_{\mathrm{H}} 1.75(4-\mathrm{Me})$ and $\delta_{\mathrm{H}} 1.31(8-\mathrm{Me})$. There were also nOe effects involving the signals at $\delta_{\mathrm{H}} 3.99(\mathrm{H}-3 \beta)$ and $\delta_{\mathrm{H}} 1.28(2-\mathrm{Me} \beta)$. These were consistent with the epoxidation of compound $\mathbf{5}$ on the $\beta$-face of the ring. ${ }^{26}$ Based on the known absolute configuration of compound $\mathbf{5}$ and the MM2 calculations, compound $\mathbf{1 1}$ has the absolute configuration $(2 R, 3 R, 4 E, 8 S, 9 S)$.

The HRMS $\left(m / z\right.$ 239.1282, $\left.\mathrm{M}-\mathrm{H}^{+}\right)$of compound 12 was consistent with the molecular formula $\mathrm{C}_{13} \mathrm{H}_{20} \mathrm{O}_{4}$.

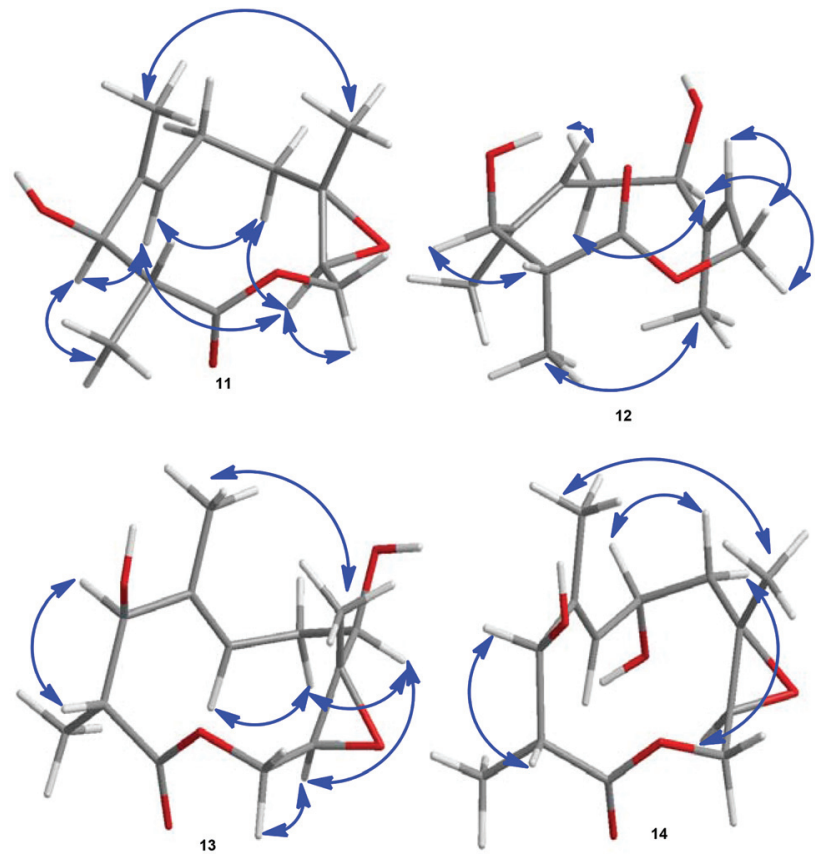

Fig. 3 MM2 minimized models with decisive nOe correlations for compounds 11-14.

The ${ }^{13} \mathrm{C}$ NMR spectrum contained 13 signals. A comparison with compound 5 showed that the resonance for C-7 [ $\left.\delta_{\mathrm{C}} 38.2(\mathrm{t})\right]$ had changed to $\delta_{\mathrm{C}} 77.2(\mathrm{~d})$ in compound 12. There were COSY correlations between $\delta_{\mathrm{H}} 4.18(\mathrm{H}-7)$ and the signals at $\delta_{\mathrm{H}} 2.46$ and 2.30 which were assigned to $\mathrm{H}-6 \alpha$ and $\mathrm{H}-6 \beta$ respectively. There were nOe effects which were observed (Fig. 3) between the signals at $\delta_{\mathrm{H}} 4.18(\mathrm{H}-7), 5.62(\mathrm{H}-9), 5.02(\mathrm{H}-5)$ and $\mathrm{H}-6 \beta$, together with $\delta_{\mathrm{H}} 4.70(\mathrm{H}-10 \beta)$ and $\mathrm{H}-9$. These were consistent with the $R$ configuration at $\mathrm{C}-7$ and hence compound 12 was $(2 R, 3 R, 4 E, 7 R, 8 E)$-3,7-dihydroxy-2,4,8-trimethyldeca-4,8dienolide.

The HRMS data for compounds $\mathbf{1 3}$ and $\mathbf{1 4}$ showed that they both had a molecular formula, $\mathrm{C}_{13} \mathrm{H}_{20} \mathrm{O}_{5}$. Their ${ }^{13} \mathrm{C}$ NMR spectra contained five $\mathrm{C}-\mathrm{O}$ signals at $\delta_{\mathrm{C}} 81.4(\mathrm{CH}, \mathrm{C}-3), 76.9$ (CH, C-7), 62.6 (C, C-8), $62.2\left(\mathrm{CH}_{2}, \mathrm{C}-10\right)$ and $56.6(\mathrm{CH}, \mathrm{C}-9)$ ppm for compound 13 and $\delta_{\mathrm{C}} 80.9(\mathrm{CH}, \mathrm{C}-3), 65.9(\mathrm{CH}, \mathrm{C}-6)$, $62.8\left(\mathrm{CH}_{2}, \mathrm{C}-10\right), 58.6(\mathrm{CH}, \mathrm{C}-9)$ and $58.0(\mathrm{C}, \mathrm{C}-8)$ ppm for 14. These compounds possessed similar ${ }^{1} \mathrm{H}$ NMR spectra in which the olefinic $\mathrm{C}-\mathrm{H}$ of compound $\mathbf{5}$ had been replaced by epoxy $\mathrm{C}-\mathrm{H}$ signals at $\delta_{\mathrm{H}} 3.09(\mathrm{dd}, J 10.0,4.0 \mathrm{~Hz})$ and $\delta_{\mathrm{H}} 3.05(\mathrm{dd}, J$ $10.2,4.2 \mathrm{~Hz}$ ) respectively. However compound 13 possessed a new $\mathrm{CH}(\mathrm{OH})$ signal at $\delta_{\mathrm{H}} 3.22(\mathrm{dd}, J 11.3,5.2 \mathrm{~Hz})(\mathrm{H}-7)$ which showed COSY correlations with signals at $\delta_{\mathrm{H}} 2.50(\mathrm{H}-6 \alpha)$ and $\delta_{\mathrm{H}} 2.32(\mathrm{H}-6 \beta)$. Compound 14 possessed a new $\mathrm{CH}(\mathrm{OH})$ signal at $\delta_{\mathrm{H}} 4.64$ (triplet $J 11.2$ of doublets $J 4.8 \mathrm{~Hz}$ ) (H-6) which showed COSY correlations with signals at $\delta_{\mathrm{H}}, 2.48(\mathrm{H}-7 \beta)$, $\delta_{\mathrm{H}} 1.12(\mathrm{H}-7 \alpha)$ and $5.20(\mathrm{H}-5)$. The nOe effects, shown in Fig. 3, were in accord with the optimized structures obtained by MM2 calculations ${ }^{24}$ and, bearing in mind the origin of the metabolites, led to the absolute stereochemistry for compounds $\mathbf{1 3}$ and $\mathbf{1 4}$ as $2 R, 3 R, 4 E, 7 R, 8 S, 9 S$ and $2 R, 3 R, 4 E, 6 R, 8 S, 9 S$ respectively. 
These mutasynthetic transformations have produced derivatives that were hydroxylated at C-6 and C-7 and regioselectively epoxidized at C-8/C9. However there was no hydration of epoxidation of the C4/C5 double bond. Consequently additional synthetic work is necessary in order to develop an efficient route for the synthesis of closer analogues of compound 4 .

Compounds 11 and 13 did not show any significant anti-bacterial activity at a concentration of 200 ppm against Escherichia coli, Bacillus subtilis or Streptococcus faecalis. ${ }^{27}$ Compounds $\mathbf{1 1}$ and $\mathbf{1 3}$ did not show any significant phytotoxic activity when tested in vivo on sterilized leaves of Phaseolus vulgaris at a concentration of 500 ppm. ${ }^{28}$

\section{Conclusions}

The regioselective ring-closing metathesis of the triene 6 has provided an efficient method for the asymmetric synthesis of (2R,3R,4E,8E)-3-hydroxy-2,4,8-trimethyldeca-4,8-dienolide $(E)$-5 in 5 steps with $26 \%$ overall yield from simple starting materials. This compound is an advanced analogue of 3,4dihydroxy-2,4,6,8-tetramethyldec-8-enolide (4) which is a scarce metabolite of $B$. cinerea. Compound 5 was biotransformed by two mutant strains of $B$. cinerea, bcbot $2 \Delta$ and $b c \Delta \Delta d 1$, into four new highly oxygenated 11-membered lactones. These mutasynthetic steps involved regioselective epoxidation of the $\mathrm{C8} / \mathrm{C} 9$ double bond and hydroxylation at either the C-6 (minor) or C-7 (major) positions. This has proved to be a valuable and versatile approach to increasing the structural diversity of 11-membered lactones. Further experiments are in progress to develop a synthesis method of compound 4 .

\section{Experimental}

\section{General procedures}

Unless otherwise noted, materials and reagents were obtained from commercial suppliers and were used without further purification. Dichloromethane was freshly distilled from $\mathrm{CaH}_{2}$ and tetrahydrofuran was dried over sodium and benzophenone and freshly distilled before use. Air- and moisture-sensitive reactions were performed under an argon atmosphere. Purification by semipreparative and analytical HPLC was performed with a Hitachi/Merck L-6270 apparatus equipped with a differential refractometer detector (RI-7490). A LiChrospher ${ }^{\circledR}$ Si $60(5 \mu \mathrm{m})$ LiChroCart ${ }^{\circledR}(250 \mathrm{~mm} \times 4 \mathrm{~mm})$ column and a LiChrospher® Si $60(10 \mu \mathrm{m})$ LiChroCart ${ }^{\circledR}(250 \mathrm{~mm} \times 10 \mathrm{~mm})$ column were used in isolation experiments. Silica gel (Merck) was used for column chromatography. TLC was performed on a Merck Kiesegel $60 \mathrm{~F}_{254}, 0.25 \mathrm{~mm}$ thick. Melting points were measured with a Reichert-Jung Kofler block and are uncorrected. Optical rotations were determined with a digital polarimeter. Infrared spectra were recorded on a FT-IR spectrophotometer and reported as wave number $\left(\mathrm{cm}^{-1}\right) .{ }^{1} \mathrm{H}$ and ${ }^{13} \mathrm{C}$ NMR measurements were recorded on Varian Unity $400 \mathrm{MHz}$, Agilent $500 \mathrm{MHz}$ and Varian Inova $600 \mathrm{MHz}$ spectrometers with $\mathrm{SiMe}_{4}$ as the internal reference at room temperature. $J$ values are given in $\mathrm{Hz}$. Chemical shifts were referenced to $\mathrm{CDCl}_{3}\left(\delta_{\mathrm{H}} 7.25, \delta_{\mathrm{C}} 77.0\right)$. NMR assignments were made using a combination of $1 \mathrm{D}$ and $2 \mathrm{D}$ techniques. Multiplicities are described using the following abbreviations: $\mathrm{s}=$ singlet, $\mathrm{d}=$ doublet, $\mathrm{t}=$ triplet, $\mathrm{q}=$ quarter; quint = quintuplet; sext = sextuplet; $\mathrm{m}=$ multiplet, $\mathrm{br}=$ broad. High-Resolution Mass Spectroscopy (HRMS) was recorded with a double-focusing magnetic sector mass spectrometer in positive ion mode or with a QTOF mass spectrometer in positive ion electrospray mode at $20 \mathrm{~V}$ cone voltage. HRESIMS/MS experiments were performed with a QTOF mass spectrometer at $20 \mathrm{~V}$ cone voltage and $10 \mathrm{eV}$ collision energy.

\section{Microorganisms}

B. cinerea mutants, bcbot $2 \Delta$ and $b c \Delta \Delta d 1$, were previously obtained by deactivating the genes encoding the sesquiterpene synthase BсBOT $2,{ }^{25}$ the synthase ВсВOT2 and the polyketide synthase BcBOA6, ${ }^{6}$ respectively, and are maintained in the BIOGER strain collection INRA (Grignon, France). Conidial stock suspensions of these strains were maintained in glycerol $(80 \%)$ at $-40^{\circ} \mathrm{C}$.

\section{Synthesis of the substrates}

(E)-2,6-Dimethylhepta-2,6-dien-1-ol (8). 2-Methylallylmagnesium chloride $(58.4 \mathrm{~mL}$ of a $0.5 \mathrm{M}$ solution in THF, $29.2 \mathrm{mmol})$ at $-30{ }^{\circ} \mathrm{C}$ was added to a stirred solution of 2-methyl-2-vinyloxirane (2 mL, $20.9 \mathrm{mmol})$ and CuI (199 mg, $1.04 \mathrm{mmol})$ in dry THF $(22 \mathrm{~mL})$ at $-30{ }^{\circ} \mathrm{C}$. The mixture was stirred at $-30{ }^{\circ} \mathrm{C}$ and, after $3 \mathrm{~h}$, was treated with a saturated ammonium chloride solution $(60 \mathrm{~mL})$ and then allowed to warm to room temperature. The aqueous layer was extracted three times with diethyl ether $(90 \mathrm{~mL})$. Combined extracts were washed with $1 \mathrm{~N} \mathrm{HCl}(200 \mathrm{~mL})$, saturated sodium bicarbonate $(200 \mathrm{~mL})$, water $(200 \mathrm{~mL})$, and brine $(200 \mathrm{~mL})$ and then dried over anhydrous sodium sulphate. Finally, the solvent was concentrated under reduced pressure and the crude was purified by silica gel column chromatography eluted with pentane$\mathrm{Et}_{2} \mathrm{O}(80: 20)$ to yield compound 8 (2756 mg, 94\%) as a colourless oil. Spectroscopic data of compound $\mathbf{8}$ were identical to those described in the literature. ${ }^{20}$

(E)-2,6-Dimethylhepta-2,6-dienal (7). TEMPO (890 mg, $5.6 \mathrm{mmol}$ ) and (diacetoxyiodo)benzene (BAIB, $18.3 \mathrm{~g}$, $83.7 \mathrm{mmol}$ ) were added at $0{ }^{\circ} \mathrm{C}$ to a solution of $(E)-2,6$ dimethylhepta-2,6-dien-1-ol (8) (3.9 g, $27.9 \mathrm{mmol})$ in dry $\mathrm{CH}_{2} \mathrm{Cl}_{2}(62 \mathrm{~mL})$. The mixture was stirred for $6 \mathrm{~h}$ and the solvent was concentrated under reduced pressure. The crude was purified by silica gel column chromatography eluted with pentane- $\mathrm{Et}_{2} \mathrm{O}(96: 4)$ to yield the aldehyde 7 (3339 $\left.\mathrm{mg}, 87 \%\right)$ as a yellow oil. IR (film) $\nu_{\text {max }} / \mathrm{cm}^{-1} 2925,2852,2769$ (CHO), 1702 (CO), 1420, 1102, 1090; ${ }^{1} \mathrm{H}$ NMR (400 MHz, $\left.\mathrm{CDCl}_{3}\right)$ $\delta_{H} 1.71(6 \mathrm{H}, \mathrm{s}, 2-\mathrm{Me}, 6-\mathrm{Me}), 2.20(2 \mathrm{H}, \mathrm{t}, J$ 7.2, 5- H), $2.49(2 \mathrm{H}, \mathrm{dq}$, J 7.2, 0.6, 4-H), 4.70 (1H, br s, 7a-H), $4.77(1 \mathrm{H}$, br s, 7b-H), 6.47 $(1 \mathrm{H}, \mathrm{tq}, J 7.2,1.0,3-\mathrm{H}), 9.38(1 \mathrm{H}, \mathrm{s}, 1-\mathrm{H}) ;{ }^{13} \mathrm{C}$ NMR $(100 \mathrm{MHz}$, $\left.\mathrm{CDCl}_{3}\right) \delta_{C} 9.1(\mathrm{q}, 2-\mathrm{Me}), 22.2(\mathrm{q}, 6-\mathrm{Me}), 26.8(\mathrm{t}, \mathrm{C} 4), 36.0(\mathrm{t}, \mathrm{C} 5)$, 110.8 (t, C7), 139.3 (s, C2), 143.9 (s, C6), 153.9 (d, C3), 195.0 
(s, C1); HRMS $\left(\mathrm{CI}^{+}\right)$: calcd for $\mathrm{C}_{9} \mathrm{H}_{14} \mathrm{O}[\mathrm{M}]^{+}$138.1044, found 138.1028.

$\left(4 R, 2^{\prime \prime} R, 3 " R, 4 " E\right)$-4-Benzyl-3-[3-hydroxy-2,4,8-trimethylnona4,8-dienoyl]-oxazolidin-2-one (10). $n$-Dibutylboron triflate (5.2 mL of a $1.0 \mathrm{M}$ solution in $\mathrm{CH}_{2} \mathrm{Cl}_{2}, 5.2 \mathrm{mmol}$ ) was added dropwise at $0{ }^{\circ} \mathrm{C}$ to a stirred solution of $(-)-(4 R)$-4-benzyl-3-propionyloxazolidin-2-one ((-)-(R)-9) (1020 m, $4.36 \mathrm{mmol})$ in dry $\mathrm{CH}_{2} \mathrm{Cl}_{2}(6.3 \mathrm{~mL})$ under argon atmosphere conditions. The mixture was stirred for $5 \mathrm{~min}$ and then $N, N^{\prime}$-diisopropylethylamine was added dropwise $(0.96 \mathrm{~mL}, 5.7 \mathrm{mmol})$. After complete addition, the mixture was stirred at $0{ }^{\circ} \mathrm{C}$ for $15 \mathrm{~min}$. The yellow solution was re-cooled to $-78{ }^{\circ} \mathrm{C}$ and a solution of $(E)-2,6$ dimethylhepta-2,6-dienal (7) (1220 mg, $8.71 \mathrm{mmol})$ was added dropwise in dry $\mathrm{CH}_{2} \mathrm{Cl}_{2}(2.0 \mathrm{~mL})$. The mixture was stirred at $-78{ }^{\circ} \mathrm{C}$ and was then allowed to warm to $0{ }^{\circ} \mathrm{C}$ and stirred for an additional hour. The reaction was quenched with a mixture of phosphate buffer $(5 \mathrm{~mL}$ of a $1.0 \mathrm{M}$ solution at $\mathrm{pH} 7)$ and $\mathrm{MeOH}(15 \mathrm{~mL})$ at $0{ }^{\circ} \mathrm{C}$ and the mixture was stirred for $5 \mathrm{~min}$. Finally, a solution of $2.4: 1 \mathrm{MeOH}-\mathrm{H}_{2} \mathrm{O}_{2}(30 \%, 15 \mathrm{~mL})$ was added slowly at $0{ }^{\circ} \mathrm{C}$ and stirred for an additional hour. The solvent was concentrated under reduced pressure and the residue was re-dissolved in diethyl ether. The aqueous layer was extracted three times with diethyl ether $(35 \mathrm{~mL})$. Combined extracts were washed with brine $(200 \mathrm{~mL})$, dried over anhydrous sodium sulphate, filtered, the solvent evaporated and the crude was purified by silica gel column chromatography eluted with petroleum ether-ethyl acetate $(75: 25)$ to yield compound $10(1126 \mathrm{mg}, 70 \%)$ as a white solid. $\mathrm{m}$. p. $37^{\circ} \mathrm{C}$ (from $\mathrm{CH}_{2} \mathrm{Cl}_{2}$ ); $[\alpha]_{\mathrm{D}}^{20}-41.3^{\circ}\left(c 0.65\right.$ in $\mathrm{CHCl}_{3}$ ); IR (film) $\nu_{\max } / \mathrm{cm}^{-1} 3524(\mathrm{OH}), 3176,2935,1781(\mathrm{CO}), 1698(\mathrm{CO}), 1456$, 1385, 1208, 1107, 886, 747; ${ }^{1} \mathrm{H}$ NMR $\left(400 \mathrm{MHz}, \mathrm{CDCl}_{3}\right) \delta_{H} 1.16$ (3H, d, $J$ 6.8, 2'-Me), 1.60 (3H, s, 4'-Me), 1.70 (3H, s, 8'-Me), $2.05\left(2 \mathrm{H}, \mathrm{t}, J\right.$ 7.4, $\left.7^{\prime}-\mathrm{H}\right), 2.18\left(2 \mathrm{H}, \mathrm{q}, J 7.4,6^{\prime}-\mathrm{H}\right), 2.77(1 \mathrm{H}, \mathrm{dd}$, $J$ 13.4, 9.2, CHHPh), 2.88 (d, $\left.J 2.8,3^{\prime}-\mathrm{OH}\right), 3.24(1 \mathrm{H}, \mathrm{dd}, J 13.4$, 3.2, CHHPh), 3.95 (1H, dq, $J$ 6.8, 3.6, 2'-H), $4.18(2 \mathrm{H}, \mathrm{m}, 5 \mathrm{a}-\mathrm{H}$, 5b-H), 4.33 (1H, br s, 3'-H), 4.64-4.66 (2H, m, 4-H, 9'a-H), 4.69 (1H, br s, 9'b-H), $5.52(1 \mathrm{H}, \mathrm{t}, J$ 7.4, 5'-H), 7.17-7.33 (5H, m, Harom); ${ }^{13} \mathrm{C}$ NMR (100 MHz, $\left.\mathrm{CDCl}_{3}\right) \delta_{C} 10.4$ (q, 2'-Me), 13.3 (q, $\left.4^{\prime}-\mathrm{Me}\right), 22.3$ (q, 8'-Me), $25.7\left(\mathrm{t}, \mathrm{C6}^{\prime}\right), 37.4(\mathrm{t}, \mathrm{C7}), 37.6(\mathrm{t}$, $\mathrm{CH}_{2} \mathrm{Ph}$ ), 40.4 (d, C2'), 55.2 (d, C4), 66.0 (t, C5), 75.1 (d, C3'), 109.9 (t, C9'), 125.7 (d, C5'), 127.3 (Carom), 128.8 (2C, Carom), 129.3 (2C, Carom), 133.6 (s, C4'), 135.0 (s, Carom), 145.3 (s, C8'), 152.9 (s, C2), 176.9 (s, C1'); HRMS $\left(\mathrm{CI}^{+}\right)$: calcd for $\mathrm{C}_{22} \mathrm{H}_{29} \mathrm{NO}_{4}[\mathrm{M}]^{+}$371.2097, found 371.2088.

$(2 R, 3 R, 4 E)$-Allyl 3 -hydroxy-2,4,8-trimethylnona-4,8-dienoate (6). Allylmagnesium bromide $(4.9 \mathrm{~mL}$ of a $1.0 \mathrm{M}$ solution in $\left.\mathrm{Et}_{2} \mathrm{O}, 4.9 \mathrm{mmol}\right)$ was added at $0{ }^{\circ} \mathrm{C}$ to alcohol $(15 \mathrm{~mL})$ under argon conditions in a Schlenk flask. The allylic mixture was stirred for $10 \mathrm{~min}$ and re-cooled at $-20{ }^{\circ} \mathrm{C}$. Then, a solution of 10 (886 mg, $2.40 \mathrm{mmol}$ ) in allylic alcohol $(3 \mathrm{~mL})$ was slowly added. When TLC monitoring indicated the completion of the reaction $(3 \mathrm{~h})$, a saturated ammonium chloride solution $(20 \mathrm{~mL})$ was added and then allowed to warm to room temperature. The aqueous layer was extracted three times with diethyl ether $(50 \mathrm{~mL})$. Combined extracts were washed with brine $(100 \mathrm{~mL})$, dried over anhydrous sodium sulphate, filtered and the solvent was concentrated under reduced pressure. The crude product was purified by silica gel column chromatography eluted with petroleum ether-Et ${ }_{2} \mathrm{O}(90: 10)$ to yield the ester $6(405 \mathrm{mg}, 67 \%)$ as a yellow oil. $[\alpha]_{\mathrm{D}}^{20}+3.7^{\circ}(c 0.42$ in $\mathrm{CHCl}_{3}$ ); IR (film) $\nu_{\max } / \mathrm{cm}^{-1} 3448(\mathrm{OH}), 2924,1736$ (CO), 1458, 1376, 1170, 1032, 888; ${ }^{1} \mathrm{H}$ NMR $\left(400 \mathrm{MHz}, \mathrm{CDCl}_{3}\right) \delta_{H} 1.15(3 \mathrm{H}$, d, J 7.1, 2-Me), $1.60(3 \mathrm{H}, \mathrm{s}, 4-\mathrm{Me}), 1.71(3 \mathrm{H}, \mathrm{s}, 8-\mathrm{Me}), 2.04(2 \mathrm{H}$, t, $J$ 7.6, 7-H), 2.13-2.20 (2H, m, 6-H), $2.25(\mathrm{~d}, J 4.4,3-\mathrm{OH}), 2.70$ $(1 \mathrm{H}, \mathrm{dq}, J 7.1,4.4,2-\mathrm{H}), 4.27(1 \mathrm{H}, \mathrm{t}, J 4.4,3-\mathrm{H}), 4.57(2 \mathrm{H}, \mathrm{dt}$, $J$ 5.6, 1.4, $\left.1^{\prime}-\mathrm{H}\right), 4.66(1 \mathrm{H}$, br s, 9b-H), $4.70(1 \mathrm{H}, \mathrm{br} \mathrm{s}, 9 \mathrm{a}-\mathrm{H}), 5.23$ (1H, ddd, $J$ 10.4, 2.8, 1.4, 3'b-H), 5.31 (1H, ddd, $J$ 17.4, 2.8, 1.4, 3'a-H), $5.47(1 \mathrm{H}, \mathrm{t}, J$ 7.0, 5-H), 5.90 (1H, ddt, $J$ 17.4, 10.4, 5.6, $\left.2^{\prime}-\mathrm{H}\right) ;{ }^{13} \mathrm{C}$ NMR (100 MHz, $\left.\mathrm{CDCl}_{3}\right) \delta_{C} 11.3$ (q, 2-Me), 12.7 (q, 4-Me), 22.5 (q, 8-Me), 25.8 (t, C6), 37.4 (t, C7), 43.0 (d, C2), 65.2 (t, C1'), 76.8 (d, C3), 110.0 (t, C9), 118.3 (t, C3'), 126.6 (d, C5), 132.0 (d, C2'), 134.0 (s, C4), 145.4 (s, C8), 175.1 (s, C1); HRMS $\left(\mathrm{CI}^{+}\right)$: calcd for $\mathrm{C}_{15} \mathrm{H}_{24} \mathrm{O}_{3}[\mathrm{M}]^{+}$252.1725, found 252.1718.

RCM of 6. (1,3-Bis(2,4,6-trimethylphenyl)-2-imidazolidinylidene)dichloro(phenylmethylene)(tricyclohexyl-phosphine) ruthenium (Grubbs ruthenium catalyst A, $121.3 \mathrm{mg}$, $0.14 \mathrm{mmol}$ ) was added to a refluxed and stirred solution of ester $6(180.0 \mathrm{mg}, 0.71 \mathrm{mmol})$ in degassed and dry $\mathrm{CH}_{2} \mathrm{Cl}_{2}$ $(420 \mathrm{~mL})$ under argon conditions. The reaction mixture was stirred until consumption of the starting material $(20 \mathrm{~h})$. The crude was filtered over a pad of silica gel and washed with ethyl acetate $(400 \mathrm{~mL})$. The solvent was removed under reduced pressure to give a crude that was purified by silica gel column chromatography eluted with ether petroleum-ethyl acetate $(90: 10)$. Final purification was carried out by semi-preparative HPLC (ether petroleum-ethyl acetate $85: 15$; flow $=$

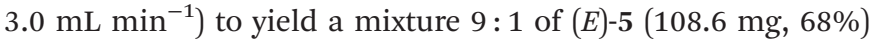
and $(Z)-5 . \uparrow$

$(2 R, 3 R, 4 E, 8 E)$-3-Hydroxy-2,4,8-trimethyldeca-4,8-dienolide $((E)-5)$. Colourless oil; $t_{\mathrm{R}}=28 \mathrm{~min} ;[\alpha]_{\mathrm{D}}^{20}+116^{\circ}(c) 0.42$ in $\mathrm{CHCl}_{3}$ ); IR (film) $\nu_{\max } / \mathrm{cm}^{-1} 3442(\mathrm{OH}), 2918,2850,1731$ (CO), 1455, 1374, 1259, 1164, 1024, 904, 794; ${ }^{1} \mathrm{H}$ NMR $(500 \mathrm{MHz}$, $\left.\mathrm{CDCl}_{3}\right) \delta_{H} 1.25(3 \mathrm{H}, \mathrm{d}, J 6.5,2-\mathrm{Me}), 1.61(3 \mathrm{H}, \mathrm{s}, 4-\mathrm{Me}), 1.71(3 \mathrm{H}$, s, 8-Me), 1.94-2.02 (1H, m, 7b-H), 2.02-2.11 (1H, m, 6b-H), 2.13-2.19 (1H, dt, $J$ 11.6, 4.0, 7a-H), 2.41 (1H, dq, $J$ 12.2, 4.0, 6a-H), $2.64(1 \mathrm{H}, \mathrm{dq}, J$ 10.0, 6.5, 2-H), $3.93(1 \mathrm{H}, \mathrm{d}, J$ 10.0, 3-H), $4.33(1 \mathrm{H}, \mathrm{t}, J 10.6,10 \mathrm{~b}-\mathrm{H}), 4.68$ (1H, dd, $J$ 10.6, 6.2, 10a-H), 5.02 $(1 \mathrm{H}, \mathrm{dd}, J 11.7,4.0,5-\mathrm{H}), 5.50(1 \mathrm{H}, \mathrm{m}, 9-\mathrm{H}) ;{ }^{13} \mathrm{C}$ NMR $\left(125 \mathrm{MHz}, \mathrm{CDCl}_{3}\right) \delta_{C} 10.2$ (q, 4-Me), 13.8 (q, 2-Me), 15.6 (q, 8-Me), 25.7 (t, C6), 38.2 (t, C7), 44.8 (d, C2), 60.9 (t, C10), 82.2 (d, C3), 122.2 (d, C9), 127.9 (d, C5), 136.4 (s, C4), 143.6 (s, C8), 175.0 (s, C1); HRMS $\left(\mathrm{CI}^{+}\right)$: calcd for $\mathrm{C}_{13} \mathrm{H}_{20} \mathrm{O}_{3}[\mathrm{M}]^{+}$224.1412, found 224.1397.

\section{Mutasynthesis experiments}

General methods. B. cinerea was grown on a surface culture in Roux bottles on a Czapek-Dox medium ( $150 \mathrm{~mL}$ per flask) comprising (per L of distilled water) glucose $(50.0 \mathrm{~g})$, yeast extract $(1.0 \mathrm{~g}), \mathrm{KH}_{2} \mathrm{PO}_{4}(5.0 \mathrm{~g}), \mathrm{NaNO}_{3}(2.0 \mathrm{~g}), \mathrm{MgSO}_{4} \cdot 7 \mathrm{H}_{2} \mathrm{O}$

I(Z)-5 could not be purified. 
$(0.5 \mathrm{~g})$, and $\mathrm{FeSO}_{4} \cdot 7 \mathrm{H}_{2} \mathrm{O}$. The $\mathrm{pH}$ of the medium was adjusted to 7.0 with aqueous $\mathrm{NaOH}(4 \mathrm{M})$. Each Roux bottle was inoculated with $2 \times 10^{6}$ fresh conidia or six uniform discs of $0.9 \mathrm{~cm}$ diameter mycelia of four-day old culture on malta agar. A filter-sterilised aqueous solution of the labeled precursor or a solution of $(E)-5$ in ethanol was fed at a carefully determined optimum time. Roux bottles were incubated at $25 \pm 2{ }^{\circ} \mathrm{C}$ in daylight under static conditions for the optimum period of time. The culture medium and mycelia were then separated by filtration. The broth was separated with $\mathrm{NaCl}$ and extracted with ethyl acetate $(3 \times)$ and dried over anhydrous $\mathrm{Na}_{2} \mathrm{SO}_{4}$. The organic extract obtained was evaporated under reduced pressure to dryness.

Feeding of $(2 R, 3 R, 4 E, 8 E)$-3-hydroxy-2,4,8-trimethyldeca-4,8dienolide $((E)-5)$ to $B$. cinerea bcbot $2 \Delta$ and $b c \Delta \Delta d 1$. Compound $(E)-5(120 \mathrm{mg})$, dissolved in EtOH $(960 \mu \mathrm{L})$, was distributed among 6 Roux bottles containing a 4-day old culture of B. cinerea bcbot $2 \Delta$ or $b c \Delta \Delta d 1$ and grown for a further 6 days. Filtration, ethyl acetate extraction and column chromatography, followed by analytical HPLC purification, gave 11, 12, 13 and 14 in the yields shown in Table 1.

$(2 R, 3 R, 4 E, 8 S, 9 S)-8,9-E$ poxy-3-hydroxy-2,4,8-trimethyldec-4enolide (11). Colourless oil; $t_{\mathrm{R}}=27 \mathrm{~min}$, petroleum etherethyl acetate $(77: 23)$, flow $=0.8 \mathrm{~mL} \mathrm{m^{-1 }} ;[\alpha]_{\mathrm{D}}^{20}+184^{\circ}(c 0.34$ in $\mathrm{CHCl}_{3}$ ); IR (film) $\nu_{\max } / \mathrm{cm}^{-1} 3448(\mathrm{OH}), 1734(\mathrm{CO}), 1458$, 1165, 1022, 887, 764; ${ }^{1} \mathrm{H}$ NMR (400 MHz, $\left.\mathrm{CDCl}_{3}\right) \delta_{H} 1.08(3 \mathrm{H}$, $\mathrm{dt}, J$ 13.4, 4.8, 7b-H), 1.28 (3H, d, $J$ 6.6, 2-Me), 1.31 (3H, s, 8$\mathrm{Me}), 1.75$ (3H, t, J 1.6, 4-Me), 2.08-2.16 (2H, m, 6b-H, 7a-H), 2.37-2.48 (1H, m, 6a-H), 2.72 (1H, dq, J 10.0, 6.6, 2-H), 3.01 (1H, dd, J 10.0, 4.2, 9-H), 3.53 (1H, dd, J 10.8, 10.0, 10b-H), 3.99 (1H, dd, J 10.0, 1.8, 3-H), 4.86 (1H, dd, J 10.8, 4.2, 10a-H), $5.17(1 \mathrm{H}, \mathrm{ddd}, J 12.0,3.2,1.6,5-\mathrm{H}) ;{ }^{13} \mathrm{C}$ NMR $(100 \mathrm{MHz}$, $\mathrm{CDCl}_{3}$ ) $\delta_{C} 10.3$ (q, 4-Me), 13.6 (q, 2-Me), 15.9 (q, 8-Me), 24.3 (t, C6), 37.0 (t, C7), 43.6 (d, C2), 58.6 (d, C9), 59.8 (s, C8), 62.9 (t, C10), 81.6 (d, C3), 126.9 (d, C5), 136.2 (s, C4), 174.4 (s, C1); HRMS $\left(\mathrm{CI}^{+}\right)$: calcd for $\mathrm{C}_{13} \mathrm{H}_{20} \mathrm{O}_{4}[\mathrm{M}]^{+}$240.1362, found 240.1353 .

$(2 R, 3 R, 4 E, 7 R, 8 E)-3,7-D i h y d r o x y-2,4,8$-trimethyldeca-4,8-dienolide (12). Colourless oil; $t_{\mathrm{R}}=28 \mathrm{~min}$, petroleum ether-ethyl acetate $(53: 47)$, flow $=0.8 \mathrm{~mL} \min ^{-1} ;[\alpha]_{\mathrm{D}}^{20}+219^{\circ}(c 0.31$ in $\mathrm{CHCl}_{3}$ ); IR (film) $\nu_{\text {max }} / \mathrm{cm}^{-1} 3395(\mathrm{OH}), 2923,1707$ (CO), 1458, 1354, 1258, 1168, 1021, 935, 851, 750; ${ }^{1} \mathrm{H}$ NMR $(400 \mathrm{MHz}$, $\left.\mathrm{CDCl}_{3}\right) \delta_{H} 1.24$ (3H, d, $J$ 6.6, 2-Me), 1.64 (3H, t, $J$ 1.2, 4-Me), 1.75 (3H, d, J 1.2, 8-Me), 2.25-2.32 (1H, m, 6b-H), $2.46(1 \mathrm{H}$, ddd, $J$ 13.6, 12.0, 11.2, 6a-H), 2.61 (1H, dq, $J$ 10.2, 6.6, 2-H), 3.90 (1H, d, J 10.2, 3-H), 4.18 (1H, dd, J 11.2, 5.6, 7-H), 4.37 (1H, t, J 10.2, 10b-H), 4.70 (1H, dd, J 10.2, 6.0, 10a-H), 5.02 (1H, dd, J 12.0, 2.4, 5-H), 5.62 (1H, dd, J 10.2, 6.0, 9-H); ${ }^{13} \mathrm{C}$ NMR (100 MHz, $\mathrm{CDCl}_{3}$ ) $\delta_{C} 10.1$ (q, C8), 10.2 (q, C4), 13.8 (q, C2), 34.5 (t, C6), 44.0 (d, C2), 60.1 (t, C10), 77.2 (d, C7), 81.9 (d, C3), 121.2 (d, C9), 124.7 (d, C5), 137.3 (s, C4), 145.2 (s, C8), 174.8 (s, C1); HRMS $\left(\mathrm{CI}^{+}\right)$: calcd for $\mathrm{C}_{13} \mathrm{H}_{19} \mathrm{O}_{4}[\mathrm{M}-\mathrm{H}]^{+}$ 239.1283, found 239.1283.

$(2 R, 3 R, 4 E, 7 R, 8 S, 9 S)-8,9-E p o x y-3,7-d i h y d r o x y-2,4,8$-trimethyldec-4-enolide (13). Colourless oil; $t_{\mathrm{R}}=31 \mathrm{~min}$, petroleum ether-ethyl acetate $(53: 47)$, flow $=0.8 \mathrm{~mL} \mathrm{~min}^{-1} ;[\alpha]_{\mathrm{D}}^{20}+94.1^{\circ}$ (c 0.47 in $\mathrm{CHCl}_{3}$ ); IR (film) $\nu_{\text {max }} / \mathrm{cm}^{-1} 3431(\mathrm{OH}), 2922,2855$ (CH), 1716 (CO), 1448, 1373, 1254, 1166, 1019, 848, 741; ${ }^{1} \mathrm{H}$ NMR (400 MHz, $\mathrm{CDCl}_{3}$ ) $\delta_{H} 1.28$ (3H, d, $J$ 6.8, 2-Me), 1.34 (3H, s, 8-Me), 1.77 (3H, d, J 1.6, 4-Me), 2.28-2.35 (1H, m, 6b-H), 2.50 (1H, dt, $J$ 13.6, 11.8, 6a-H), 2.69 (1H, dq, $J$ 9.8, 6.8, 2-H), 3.09 (1H, dd, J 10.0, 4.0, 9-H), 3.22 (1H, dd, J 11.8, 5.2, 7-H), 3.56 $(1 \mathrm{H}, \mathrm{dd}, J 10.8,10.0,10 \mathrm{~b}-\mathrm{H}), 3.97$ (1H, d, J 9.8, 3-H), $4.89(1 \mathrm{H}$, $\mathrm{dd}, J 10.8,4.0,10 \mathrm{a}-\mathrm{H}), 5.12$ (1H, dd, $J 11.8,3.2,5-\mathrm{H}) ;{ }^{13} \mathrm{C} \mathrm{NMR}$ $\left(100 \mathrm{MHz}, \mathrm{CDCl}_{3}\right) \delta_{C} 10.2$ (q, 8-Me), 10.5 (q, 4-Me), 13.6 (q, 2-Me), 32.5 (t, C6), 43.4 (d, C2), 56.6 (d, C9), 62.2 (t, C10), 62.6 (s, C8), 76.9 (d, C7), 81.4 (d, C3), 122.5 (d, C5), 137.6 (s, C4), 174.4 (s, C1); HRMS $\left(\mathrm{CI}^{+}\right.$): calcd for $\mathrm{C}_{13} \mathrm{H}_{20} \mathrm{O}_{5}[\mathrm{M}]^{+}$256.1311, found 256.1310.

$(2 R, 3 R, 4 E, 6 R, 8 S, 9 S)-8,9-E p o x y-3,6$-dihydroxy-2,4,8-trimethyldec-4-enolide (14). Colourless oil; $t_{\mathrm{R}}=38 \mathrm{~min}$, petroleum ether-ethyl acetate $(30: 70)$, flow $=0.8 \mathrm{~mL} \mathrm{~min}^{-1} ;[\alpha]_{\mathrm{D}}^{20}+46.3^{\circ}$ (c 0.11 in $\mathrm{CHCl}_{3}$ ); IR (film) $\nu_{\max } / \mathrm{cm}^{-1} 3422(\mathrm{OH}), 2921,2856$ (CH), 1719 (CO), 1458, 1387, 1259, 1172, 1028, 932, 824; ${ }^{1} \mathrm{H}$ NMR (600 MHz, $\left.\mathrm{CDCl}_{3}\right) \delta_{H} 1.12(1 \mathrm{H}, \mathrm{t}, J 11.2,7 \mathrm{~b}-\mathrm{H}), 1.30(3 \mathrm{H}$, d, $J$ 6.6, 2-Me), 1.32 (3H, s, 8-Me), 1.83 (3H, d, J 1.2, 4-Me), 2.48 (1H, dd, $J$ 11.2, 4.8, 7a-H), 2.72 (1H, dq, $J$ 10.2, 6.6, 2-H), 3.05 (1H, dd, J 10.2, 4.2, 9-H), 3.49 (1H, dd, J 10.8, 10.2, 10b-H), 4.00 (1H, dd, J 10.2, 1.2, 3-H), 4.64 (1H, dt, J 11.2, 4.8, 6- $\mathrm{H}$ ), 4.90 (1H, dd, $J 10.8,4.2,10 \mathrm{a}-\mathrm{H}), 5.20(1 \mathrm{H}, \mathrm{d}, J 11.2,5-\mathrm{H}) ;{ }^{13} \mathrm{C}$ NMR (150 MHz, $\mathrm{CDCl}_{3}$ ) $\delta_{C} 10.7$ (q, 4-Me), 13.5 (q, 2-Me), 17.1 (q, 8-Me), 43.7 (t, C7), 45.6 (d, C2), 58.0 (s, C8), 58.6 (d, C9), 62.8 (t, C10), 65.9 (d, C6), 80.9 (d, C3), 129.4 (d, C5), 139.0 (s, C4), 174.1 (s, C1); HRMS $\left(\mathrm{CI}^{+}\right)$: calcd for $\mathrm{C}_{13} \mathrm{H}_{21} \mathrm{O}_{5}[\mathrm{M}+\mathrm{H}]^{+}$ 257.1389, found 257.1387 .

\section{Acknowledgements}

This research was supported by grants from MICINN (AGL2012-39798-C02-01) and from the Junta de Andalucía (P07-FQM-02689). José Manuel Botubol is grateful to the Junta de Andalucia for his research fellowship. We gratefully acknowledge Dr Muriel Viaud from the UMR BIOGER, INRA (Versailles, France) and P. Tudzynski from Munster University (Germany) for the supply of $B$. cinerea mutant strains. The use of NMR and mass spectrometry (QTOF) facilities at the Servicio Centralizado de Ciencia y Tecnología (SCCYT) of the University of Cádiz is acknowledged.

\section{Notes and references}

1 Y. Elad, B. Williamson, P. Tudzynski and N. Delen, in Botrytis: Biology, pathology and control, Springer, 2007.

2 I. G. Collado, A. J. Macías-Sánchez and J. R. Hanson, Nat. Prod. Rep., 2007, 24, 674-686.

3 H. Tani, H. Koshino, E. Sakuno, H. G. Cutler and H. Nakajima, J. Nat. Prod., 2006, 69, 722-725.

4 J. Moraga, C. Pinedo, R. Durán-Patrón, I. G. Collado and R. Hernández-Galán, Tetrahedron, 2011, 67, 417-420. 
5 J. L. Reino, R. Durán-Patrón, M. Daoubi, I. G. Collado and R. Hernández-Galán, J. Org. Chem., 2006, 71, 562-565.

6 B. Dalmais, J. Schumacher, J. Moraga, P. Le Pecheur, B. Tudzynski, I. G. Collado and M. Viaud, Mol. Plant Pathol., 2011, 12, 564-579.

7 M. Massaroli, J. Moraga, K. Bastos Borges, J. RamírezFernández, M. Viaud, I. G. Collado, R. Durán-Patrón and R. Hernández-Galán, ChemBioChem, 2013, 14, 132-136.

8 G. Rousseau, Tetrahedron, 1995, 51, 2777-2849.

9 H. M. C. Ferraz, F. I. Bombonato, M. K. Sano and L. S. Longo Jr., Quim. Nova, 2008, 31, 885-900.

10 J. W. Wong, V. Verigin, A. C. Oehlschlager, J. H. Borden, H. D. Pierce Jr., A. M. Pierce and L. Chong, J. Chem. Ecol., 1983, 9, 451-474.

11 (a) T. Chuman, J. Sivinski, R. R. Heath, C. O. Calkins, J. H. Tumlinson, M. A. Battiste, R. L. Wydra, L. Strekowski and J. L. Nation, Tetrahedron Lett., 1988, 29, 6561-6563; (b) W. P. Ponce, J. L. Nation, T. C. Emmel, B. J. Smittle and P. E. A. Teal, J. Chem. Ecol., 1993, 19, 3045-3056; (c) J. R. Rocca, J. L. Nation, L. Strekowski and M. A. Battiste, J. Chem. Ecol., 1992, 18, 223-244; (d) I. S. Lima, P. E. House and R. R. Nascimento, J. Braz. Chem. Soc., 2001, 12, 196-201.

12 S. B. Singh, H. Jayasuriya, D. L. Zink, J. D. Polishook, A. W. Dombrowski and H. Zweerink, Tetrahedron Lett., 2004, 45, 7605-7608.

13 (a) M. A. Battiste, J. R. Rocca, R. L. Wydra, J. H. Tumlinson III and T. Chuman, Tetrahedron Lett., 1988, 29, 6565-6567; (b) K. Mori and Y. Nakazono, Liebigs Ann. Chem., 1988, 167-174; (c) B. A. Cheskis, N. A. Shpiro and A. M. Moiseenkov, Russ. Chem. Bull., 1989, 38, 2389-2393; (d) G. H. Del Vecchio and A. C. Oehlschlager, J. Org. Chem., 1994, 59, 4853-4857.

14 T. Moriya, Y. Handa, J. Inanaga and M. Yamaguchi, Tetrahedron Lett., 1988, 29, 6947-6948.

15 For the synthesis of 11-membered lactones via RCM, see: (a) H. El Sukkari, J.-P. Gesson and B. Renoux, Tetrahedron Lett., 1998, 39, 4043-4046; (b) S. C. Cho, P. H. Dussault, A. D. Lisec, E. C. Jensen and K. W. Nickerson, J. Chem. Soc., Perkin Trans. 1, 1999, 193-196; (c) J. D. Winkler, J. M. Holland, J. Kasparec and P. H. Axelsen, Tetrahedron, 1999, 55, 8199-8214; (d) M. D. Ronsheim and C. K. Zercher,
J. Org. Chem., 2003, 68, 1878-1885; (e) J. Pospisil, C. Mueller and A. Fuerstner, Chem. - Eur. J., 2009, 15, 5956-5968; (f) M. Lejkowski, P. Banerjee, S. Schueller, A. Muench, J. Runsink, C. Vermeeren and H.-J. Gais, Chem. - Eur. J., 2012, 18, 3529-3548.

16 A. Fürstner, K. Radkowski, C. Wirtz, R. Goddard, C. W. Lehmann and R. Mynott, J. Am. Chem. Soc., 2002, 124, 7061-7069.

17 K. Welmar, R. Tschesche and E. Breitmaier, Chem. Ber., 1979, 112, 3598-3602.

18 H. Tani, H. Koshino, E. Sakuno and H. Nakajima, J. Nat. Prod., 2005, 68, 1768-1772.

19 J. Kennedy, Nat. Prod. Rep., 2008, 25, 25-34.

20 D. Yang and M. Xu, Org. Lett., 2001, 3, 1785-1788.

21 A. De Mico, R. Margarita, L. Parlanti, A. Vescovi and G. Piancatelli, J. Org. Chem., 1997, 62, 6974-6977.

22 D. A. Evans, J. Bartroli and T. L. Shih, J. Am. Chem. Soc., 1981, 103, 2127-2129.

23 (a) P. Schwab, M. B. France, J. W. Ziller and R. H. Grubbs, Angew. Chem., Int. Ed. Engl., 1995, 34, 2039-2041; (b) P. Schwab, R. H. Grubbs and J. W. Ziller, J. Am. Chem. Soc., 1996, 118, 100-110.

24 Energy minimization of compounds $(Z)-5,(E)-5$ and 11-14 were carried out on the basis of MM2 force field from CS Chem 3D Ultra 12.0. For an overview regarding the use of MM2 for minimizations, see: (a) D. A. Evans, C. E. Masse and J. Wu, Org. Lett., 2002, 4, 3375-3378; (b) Z.-J. Zhan, S.-P. Yang and J.-M. Yue, J. Org. Chem., 2004, 69, 17261729; (c) A. Sharma, A. Mishra, R. P. Prajapat, S. Jain and A. Bhandari, J. Chem. Pharm. Res., 2010, 2, 682-689; (d) K. Simon, J. Wefer, E. Schöttner and T. Lindel, Angew. Chem., Int. Ed., 2012, 51, 10889-10892.

25 C. Pinedo, C.-M. Wang, J. M. Pradier, B. Dalmais, M. Choque, P. Le Pecheur, G. Morgant, I. G. Collado, D. Cane and M. Viaud, ACS Chem. Biol., 2008, 3, 791-801.

26 A. Rose, K. R. Hanson, K. D. Wilkinson and M. J. Wimmer, Proc. Natl. Acad. Sci. U. S. A., 1980, 77, 2439-2441.

27 R. Durán-Patrón, R. Hernández-Galán, L. G. Rebordinos, J. M. Cantoral and I. G. Collado, Tetrahedron, 1999, 55, 2389-2400.

28 L. Rebordinos, J. M. Cantoral, M. V. Prieto, J. R. Hanson and I. G. Collado, Phytochemistry, 1996, 42, 383-387. 